\title{
Behaviour of Composite Columns and Girders in Fire
}

\author{
KARL KORDINA \\ Technical University of Braunschweig \\ Institut fuer Baustoffe \\ Massivbau und Brandschutz \\ Braunschweig, FRG
}

\section{ABSTRACT}

In the recent years the dimensioning of composite columns and girders with respect to their fire resistance has been studied according to Iso 834 on the basis of theoretical and experimental investigations. The present report shows in which way these results can be incorporated in a fire design quide. Tables dealing with the fire resistance of composite columns with concrete filled hollow steel sections, of composite columns with steel sections completely embedded in concrete and of columns concreted between the flanges are prepared. In addition the report shows the design of composite girders and the joints to adjacent columns with respect to their fire resistance.

\section{INTRODUCTION}

The dimensioning and construction of composite column and girders for normal temperatures is regulated in DIN 18806 Part 1 (03.84) or the guidelines for the dimensioning and construction of composite girders. Within recent years numerous investigations into the fire behaviour of composite structures have been carried out, and these results should be made generally available for practical application, in order to avoid the verification of these building members by an expert's report. The existing experimental investigations have been carried out in accordance with the requirements of DIN 4102, Part 2, and therefore these results, relevantly prepared, can be incorporated into DIN 4102, Part 4. However, it should be noted, that additional constructive references with regard to the degree of loading, the joints between composite steel column and composite steel girders and the load transfer into the column core have to be observed in order to fulfill the requirements of the fire resistance classes of DIN $4102 / 1-5,9 /$.

In the following it is assumed, that for a structural fire design of composite girders the dimensioning for normal temperatures is carried out for the loading case $\mathrm{H}$, but for composite columns for the loading case $\mathrm{HZ}$. The classification under fire exposure is based on the behaviour of the single construction members, as it is the case for all construction members covered by DIN 4102, Part 4. This means, that the effects of displacements within the whole structure, e.g. horizontal displacements of column ends, remain disregarded. 
The following design directions consider the use of commercial rolled steel sections of steel st $37-2$ and St $52-3$ according to DIN 17.100 (01.80) and of welded sections, provided that the ratios of flange/webplate thickness, profile-width/web-plate thickness or profile diameter/wall thickness etc. are regarded. As long as nothing contrary is stated, the directions are valid for both steel qualities /10/.

\section{COMPOSITE COLUMNS}

For the assessment of the fire behaviour of composite columns Euler-case 4 was always assumed, because the requirement, that the loadings from the adjoining girders have to be transfered into the column core always leads to joints between the girders and the column ends which, in the case of fire, cause a certain restrain of the rotations of the column ends. Because of the loss in stiffness of the column under fire exposure, this restrain of the end rotations acts like a restraint of the column ends $/ 9 /$.

The tabulated values for the minimum section dimensions of the composite columns, depending on the fire resistance classes, have been derived under the assumption that the loading in the case of fire is equal to the permissible load, determined under the assumption of Euler-case 2 (both ends being simply supported). Eccentric loading results in a reduction of the permissible loads for normal design, and therefore has to be taken as the basis for the design in case ot fire.

It is permitted to take additional longitudinal reinforcement steel in the design for normal temperatures into account.

If, for the determination of the existing load under service conditions for a certain column within the building, a restrain of the end rotations was already taken into account (e.g. the case within frame like structures), a higher permissible column load, circumstances permitted, than for the assumption of both ends simply supported can be obtained. In these cases more exact design methods are necessary.

\section{Composite Columns of Filled Hollow Sections}

Under fire exposure the outer, unprotected steel sections show, after a short time, a high loss of load-bearing capacity. In order to avoid a premature failure by buckling of the steel sections, the column cores have to be designed with an appropriate load-bearing capacity. The use of a higher wall thickness or higher graded steel for the hollow sections is not advantageous with regard to the fire protection requirements. The tabulated values for hollow steel sections have therefore only been determined for a steel grade st 37. An efficient increase in the load-bearing capacity under fire exposure is achieved by reinforcement steel within the concrete core $/ 7 /$.

This additional reinforcement has to be fixed in position by stirrups and spacers. The hollow section has to be provided with openings, at intervals of at least $5.0 \mathrm{~m}$, as well as at the top and the bottom of the column. These openings, which under fire exposure serve as steam-pressure release, must have a sectional area of at least $6.0 \mathrm{~cm}^{2}$ and have to be free of hardened concrete. 
A survey of composite columns with concrete filled hollow sections and a secured fire resistance time is given in Fig. 1 .

\section{Composite Columns with Completely Embedded steel Sections}

With the minimum concrete cover of the steel section of $40 \mathrm{~mm}$, a fire resistance time of 60 mins. ( $F$ 60) is normally achieved without a reduction of the permissible load under normal temperatures. For a fire resistance class F 90 a minimum concrete cover of $50 \mathrm{~mm}$ is necessary. The concrete cover has to be secured by longitudinal reinforcement - at least one bar in each corner of the cross section - as well as by stirrups. The minimum axis distances of this longitudinal reinforcement has to be observed, the disign of this reinforcement (stirrup distances, bar diameter etc.) has to be carried out in accordance with DIN 1045 $18 /$.

\section{Composite Columns Concreted Between the Flanges}

This kind of composite columns can be designed for a fire resistance time up to 60 mins. Without a reduction of the permissible load under normal temperatures. For higher fire resistance times reductions of the permissible load are necessary. An improvement of the behaviour in fire can be achieved with additional reinforcement.

In order to secure the concrete between the flanges against dropping out, it has to be fixed to the web-plate by stirrups or stud connectors (see Fig. 5). The stirrups have to be welded to the web-plate, or reinforcement hooks have to be passed through a boring in the web-plate and fixed to the reinforcement; stud connectors have to be welded to the web-plate. For the positioning of the stirrups longitudinal reinforcement bars have to be arranged in the outer corners of the concrete cross section. The distance between these connectors (welded-stud connectors, reinforcement hooks or stirrups) in longitudinal direction must be less than $500 \mathrm{~mm}$; in order to secure the load transfer into the conrete, the stirrup distance in the region of joints has to be reduced on a length of $500 \mathrm{~mm}$ to less than $500 \mathrm{~mm}$. For columns with rolled steel sections and an inner flange distance of more than $400 \mathrm{~mm}$, the connectors (welded-stud connectors and hooks) have to be arranged in two rows. Corresponding guidelines -analogously used-are given in Figs. 5,6 and 7.

Design examples with secured fire resistance time are given in Fig. 3 .

\section{COMPOSITE GIRDERS}

For constructive and economical reasons it is often requested to keep the bottom flange of the section accessible. In these cases, the requested fire resistance time can be achieved by concreting the space between the flanges and, if necessary, by additional longitudinal reinforcement. In the case of fire exposure, parts of the loading of the bottom flange, which is rapidly loosing its strength, is transferred into this additional reinforcement and therefore must not be taken into account for the design at normal temperatures /10/. 


\begin{tabular}{|ll|r|r|r|r|}
\hline & & & \\
\hline
\end{tabular}

a: reduced admissible load in relation to the admissible load acc. DIN 18806 part 1, loading case $H Z$

Fig.1: Min. dimensions, min. percentage of reinforcement and min. axis distances of composite columns with filled hollow sections

Steel quality: St. 37 , Concrete $>$ B 25, addit. reinforcement BSt $500 \mathrm{~S}$

(If St 52 is used allow. Steel stress $B_{5}=240 \mathrm{~N} / \mathrm{mm}^{2}$ for the evaluation of the admissible load) 


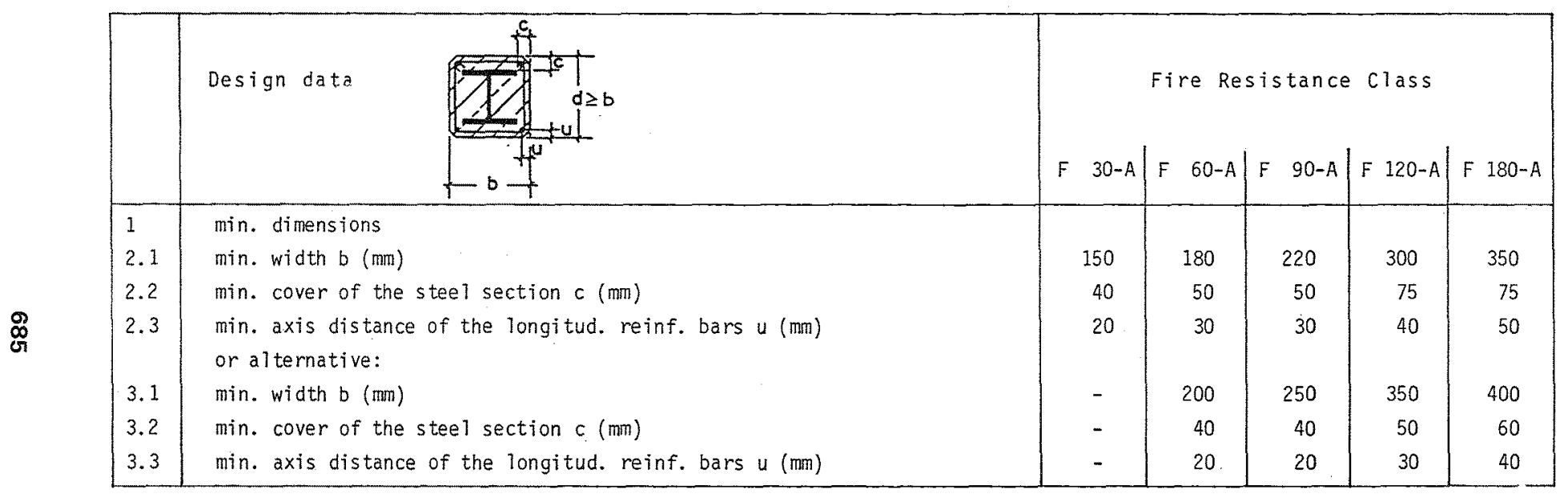

Fig. 2: Min. dimensions, min. concrete cover and axis distances of composite columns with completely embedded sections; reinforcement acc. DIN 18806 part 1 (03.84)

Add. reinf. bars BSt $500 \mathrm{~S}$, Concrete $\geq B 25$ 


\begin{tabular}{|c|c|c|c|c|c|c|}
\hline & Design data & Fi & $\begin{array}{l}\text { ire Resis } \\
\mid \text { F } 60-\mathrm{A} \mid\end{array}$ & $\begin{array}{l}\text { stance } \\
\text { F } 90-A\end{array}$ & Class & F $180-A$ \\
\hline $\begin{array}{l}1 \\
1.1 \\
1.2 \\
1.3 \\
2 \\
2.1 \\
2.2 \\
2.3 \\
3 \\
3.1 \\
3.2 \\
3.3\end{array}$ & $\begin{array}{l}\text { min. dimensions, related to a load reduction factor } \alpha=0.4 \\
\text { min. width } b \text { (mm) } \\
\text { min. axis distance of the longit. reinf. } u(m m) \\
\text { min. relation web plate/flange thickness } \mathrm{s} / \mathrm{t} \\
\text { min. dimensions related to a load reduction factor. } \alpha=0.7 \\
\text { min. width b (mm) } \\
\text { min. axis distance of the longit. reinf. } u(\mathrm{~mm}) \\
\text { min. relation web plate/flange thickness } \mathrm{s} / \mathrm{t} \\
\text { min. dimensions related to a load reduction factor } \alpha=1.0 \\
\text { min. width b (mm) } \\
\text { min. axis distance of the longit. reinf. } u(\mathrm{~mm}) \\
\text { min. relation web plate/flange thickness } \mathrm{s} / \mathrm{t}\end{array}$ & $\begin{array}{r}200 \\
35 \\
0.6\end{array}$ & $\begin{array}{r}260 \\
40 \\
0.5\end{array}$ & $\begin{array}{r}300 \\
50 \\
0.5\end{array}$ & $\begin{array}{r}300 \\
60 \\
0.7\end{array}$ & 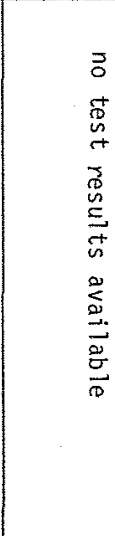 \\
\hline
\end{tabular}

$\alpha=$ reduced admissible load in relation to the admissible load acc. DIN 18806 part 1, loading case $\mathrm{HZ}$

Fig. 3: Min. dimensions, min. axis distance and min. relation web plate/flange thickness of composite columns concreted between the flanges

Concrete quality $\geq$ B 25; stirrups and longitud. reinf. BSt $500 \mathrm{~S}$ 


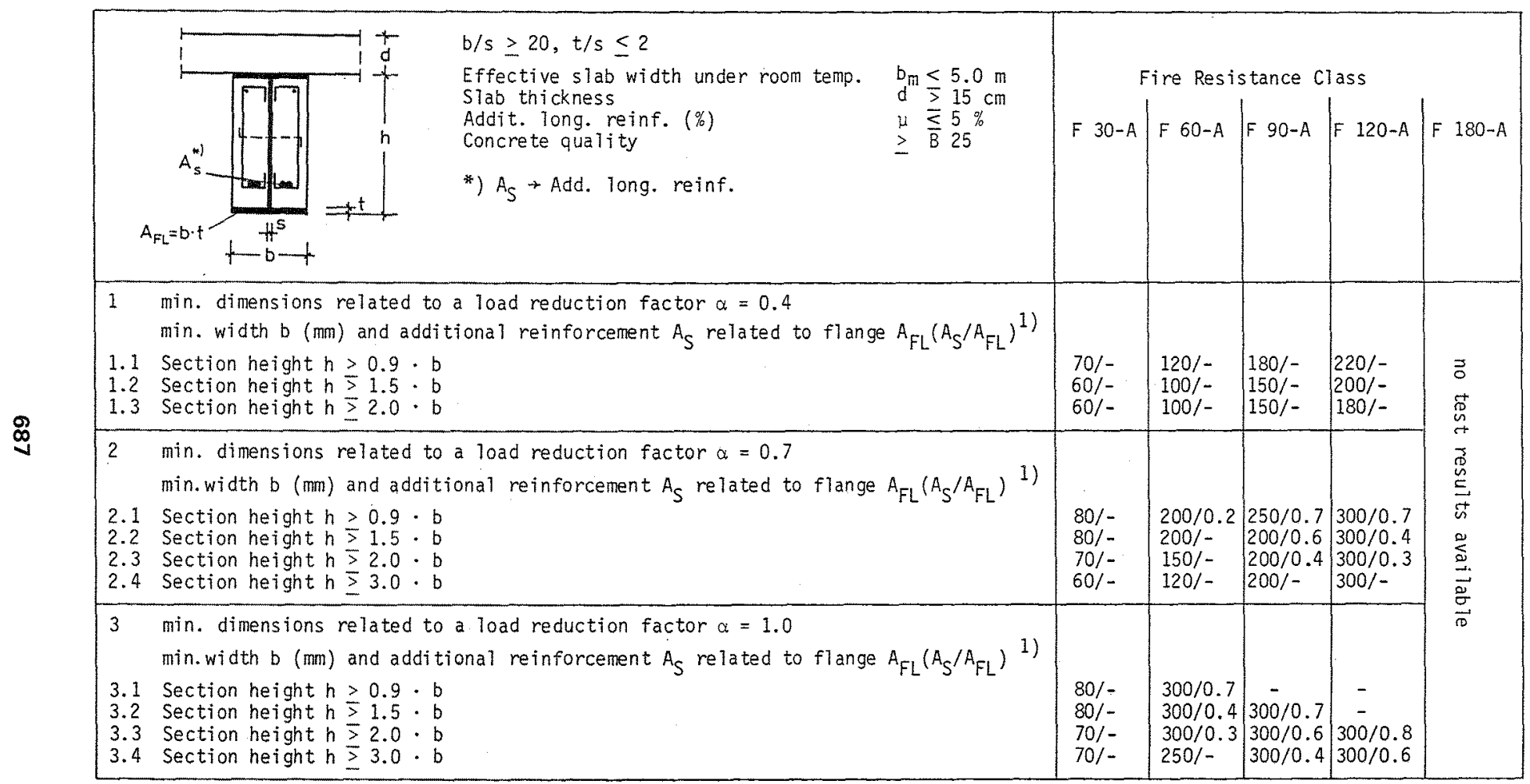

$\alpha$ : reduced admissible load related to the adm. load acc. to "Richtlinie für Stahlverbundträger", loading case $H$

1) For the use of St 37 instead of St 52 , the additional reinforcement can be reduced to $70 \%$ of the given values.

Fig. 4: Min. dimensions and additional reinforcement of composite girders concreted between the flanges 


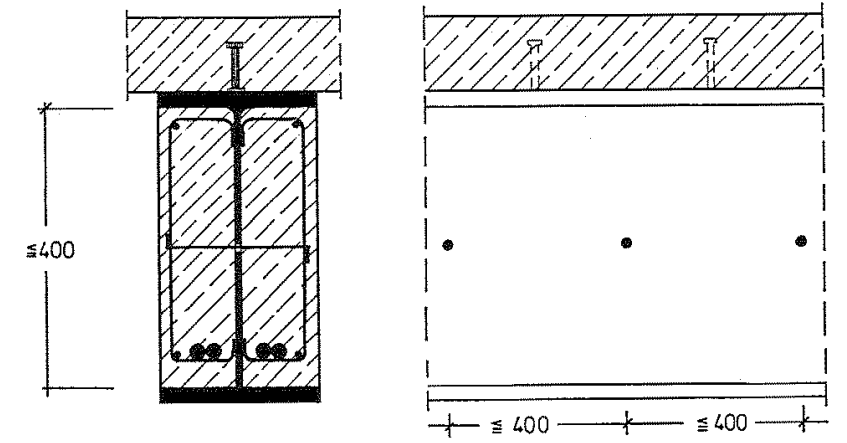

$\underset{\infty}{\infty}$

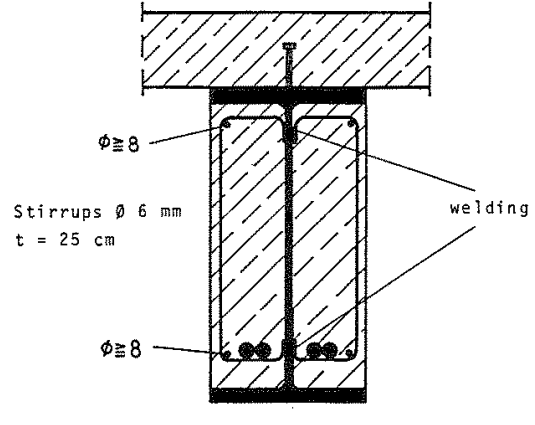

a) Stirrups welded to the steel section

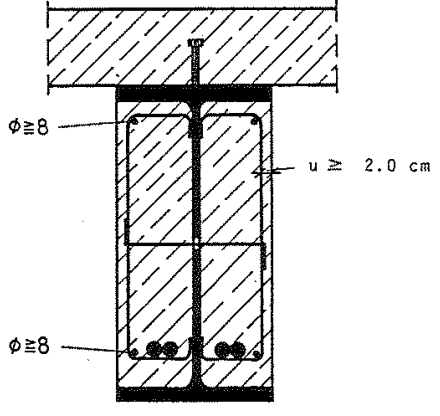

b) Hooks penetrating the web plate, fastend to stirrups

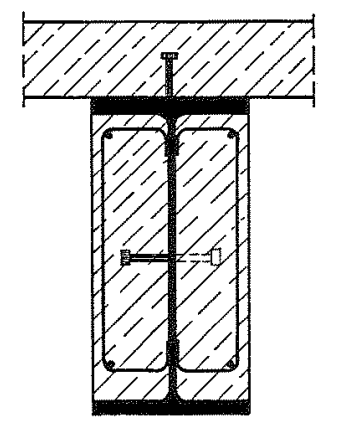

Stud connectors welded to the web plate

Fig. 5: Detailing of composite girders with $h \leqslant 400 \mathrm{~mm}$ in order to secure the concrete filling; the concrete must always be secured by stirrups and corner-bars (reinforcement bars BSt 500; concrete quality $\geq$ B 25). 

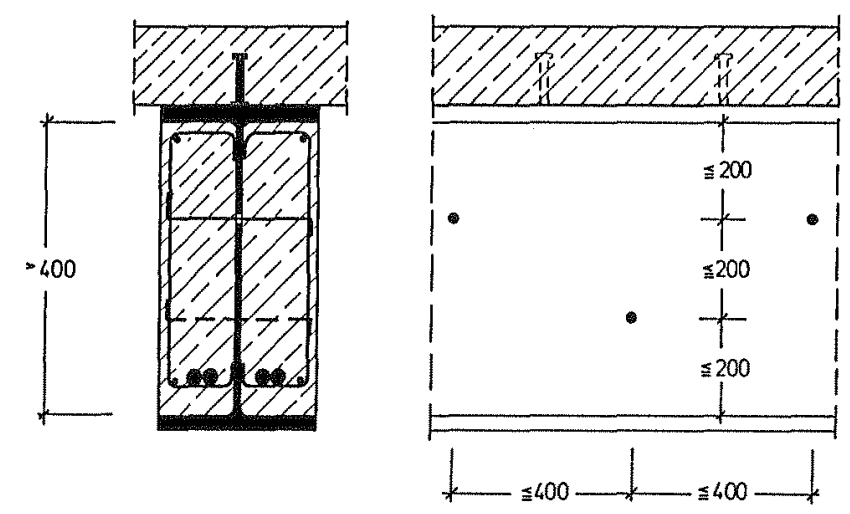

Fig. 6: Max. distances of fastening measures of the concrete filling between the flanges; heights $>400 \mathrm{~mm}$ (stirrups, hooks or welded-s tud connectors). 


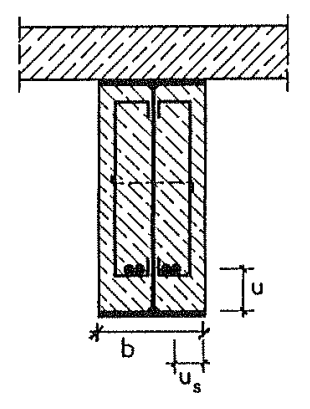

\begin{tabular}{|c|c|c|c|c|}
\hline \multirow{2}{*}{$\begin{array}{c}\text { Section width } \\
\text { b (mm) }\end{array}$} & $\begin{array}{c}\text { Axis. dist. } \\
\text { (mm) }\end{array}$ & \multicolumn{4}{|c|}{ F 60} & F 90 & F 120 \\
\hline \multirow{2}{*}{200} & $u$ & 80 & 100 & - \\
& $u_{s}$ & 40 & 55 & - \\
\hline 250 & $u$ & 60 & 75 & - \\
& $u_{s}$ & 35 & 50 & - \\
\hline 300 & $u^{*}$ & 40 & 50 & 70 \\
& $u_{s}$ & 25 & 45 & 60 \\
\hline
\end{tabular}

Fig. 7: Min. axis distances of additional reinforcement bars within composite girders. 
The concete between the flanges has always to be fixed to the web-plate by means of stirrups, hooks or welded-stud connectors. Corresponding guidelines are given in Figs. 5, 6 and 7 .

In a fire design the portion of the concrete slab, assumed as the effective width of slab for the concrete flange, can only be considered as one third of the effective width of slab for a normal design. The reason can be seen in the formation of cracks parallel to the girder, which endangers the shear transfer as considered for normal temperatures. For the time being, this assumption can be used for the fire design of reinforced light-gauge composite floor systems (minimum concrete thickness over the stiffening corrugation $=10 \mathrm{~cm}$ ) as a top flange of the composite girder, but these deck-systems have to be approved and constructed in such a way that the top flange of the rolled section is sufficiently protected against a direct fire exposure (undercut closely spaced stiffening corrugations or in-situ concrete cover in the metal deck openings).

Design examples with a secured fire resistance time are given in Fig. 4. The values given are based on a simply supported composite girder. Guidelines for the connection of the concrete between the flanges to the web-plate and the minimum axis distances of the additional reinforcement for composite girders concreted between the flanges are given in Figs. 5,6 and 7 .

\section{JOINTS BETWEEN COMPOSITE COLUMNS AND GIRDERS}

In addition the fire behaviour of different possible connections between the composite column and girder was tested. Three different possible design examples are given in Figs. 8,9 and 10. In most cases brackets, welded to the steel section of the composite column, are used, which serve as the support for the adjoining composite girders.

The welding seams of a connection to a hollow section (see Fig. 8) remain unprotected and directly exposed to the fire. Therefore the shear connection in the case of fire has to be secured by additional weldedstud connectors, dimensioned with $\gamma=1.0$ (permissible shear strength according to DIN 18806 , Part $1(03.84)) / 6 /$. The welding seam at the joint shown in Fig. 9 is protected against a direct fire exposure by the surrounding concrete.

The connection with brackets on composite columns concreted between the flanges need additional measures such as welded stud connectors because of the fire exposure of the welding seams between bracket and the steel section (see Fig. 10, left). If the joint is designed with a flap, welded to the column ( $\mathrm{Fig}$. 10, right), no additional protective measures against a fire exposure is necessary, provided that the gap between girder and column is smallex than $100 \mathrm{~mm}$; otherwise the gap has to be filled with mineral wool $/ 6 /$.

In any case all openings in girders or column, e.g because of assembling the structure, must finally be filled with mortar or mineral wool. 


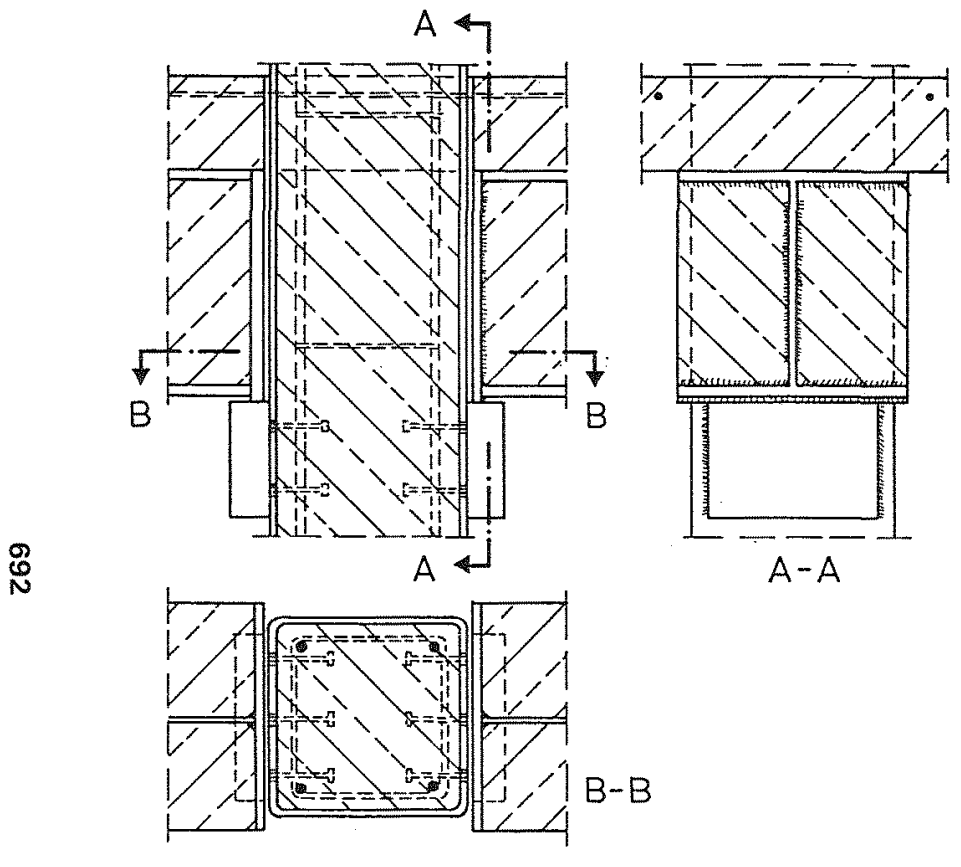

a) Bracket, back anchored by welded-stud connectors
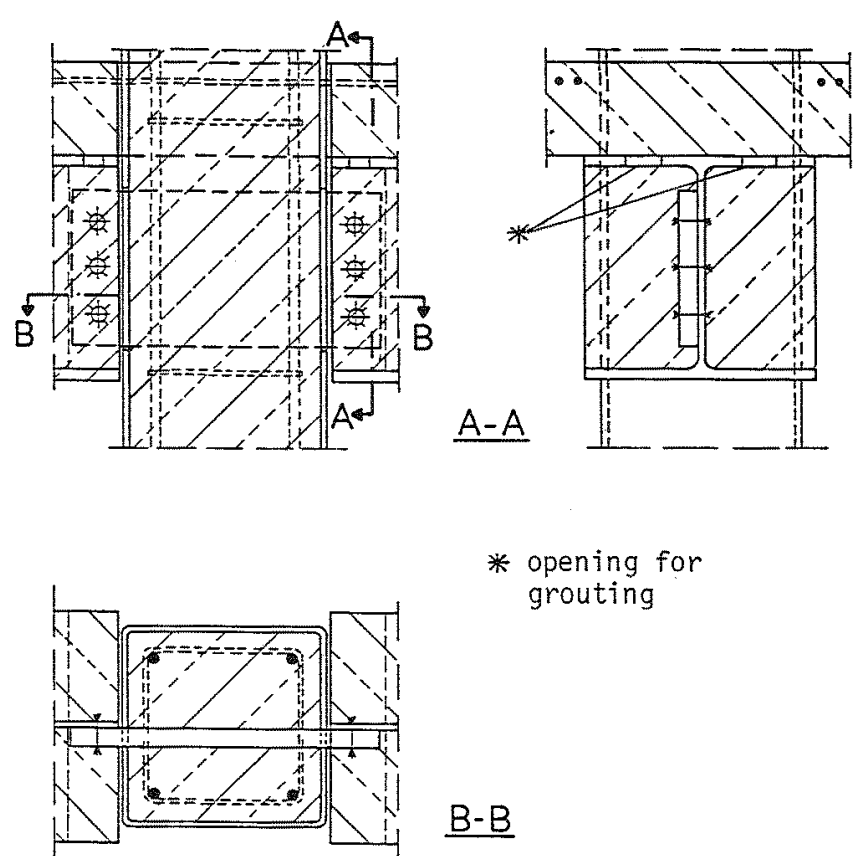

* opening for grouting

b) Steel flap, penetrating the column 


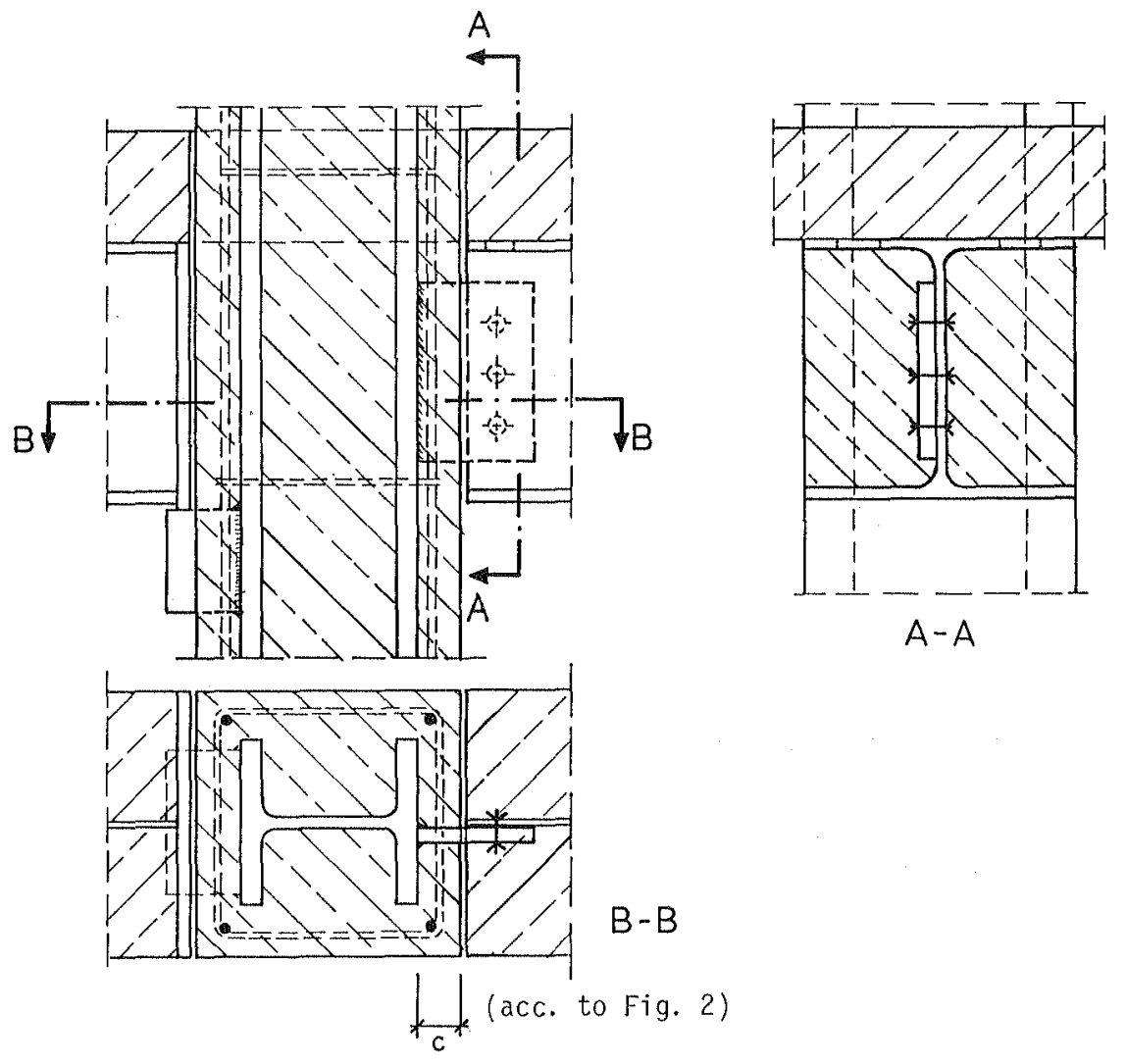

Fig. 9: Joint between a composite girder and a completely concrete encased column; the welding seams are fireprotected by the concrete of the column cross section 


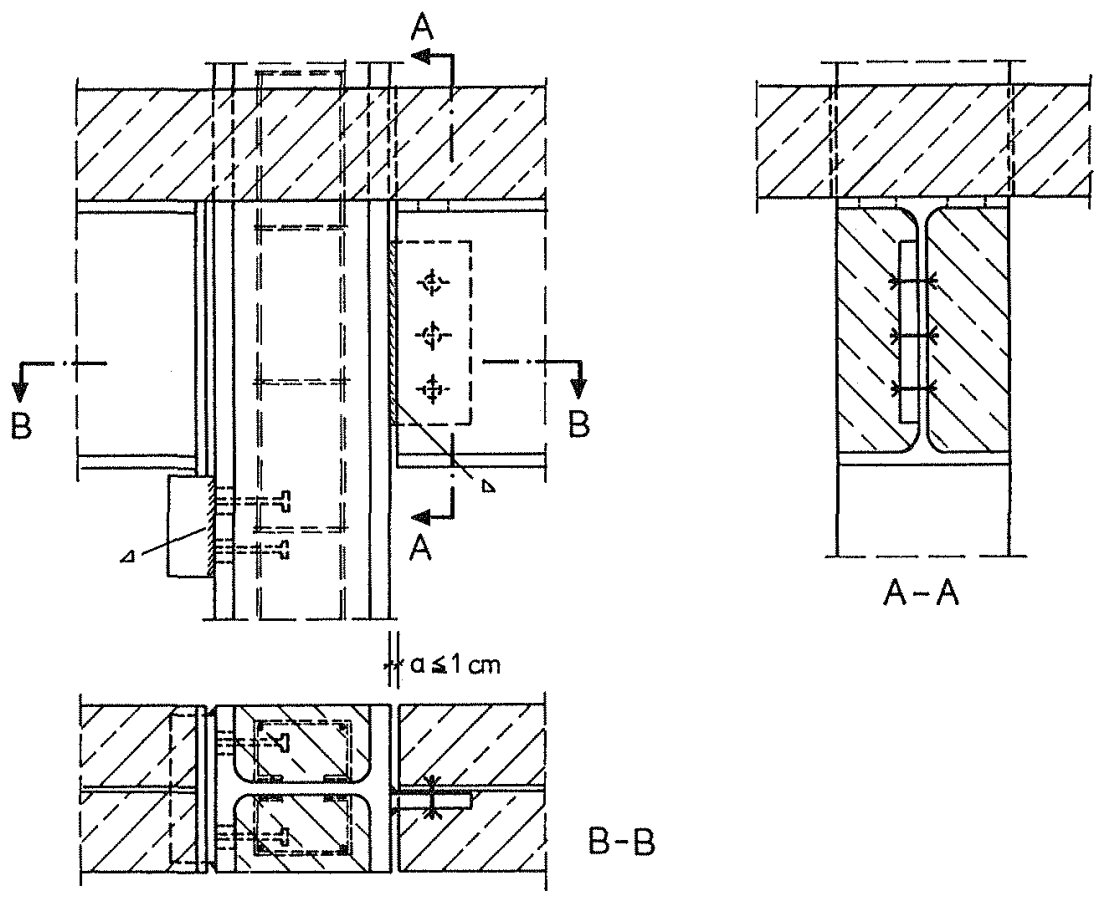

Fig. 10: Joint between a composite girder with a composite column concreted between the flanges 


\section{REFERENCES}

1// Grandjean, G.; Grimault, J. P.; Petit, L.: Détexmination de la durée au feu des profils creux remplis de béton. Forschungsbericht Cométtube, Paris, CIDECT 15 B/80-10 und Europäische Gemeinschaft für Kohle und Stahl (Nr. 7210 SA 3/302) 1980.

/2/ Kordina, K.; Klingsch, W.: Brandverhalten von stahlstützen im Verbund mit Beton und von massiven Stahlstützen ohne Beton. Studiengesellschaft für Anwendungstechnik von Eisen und Stahl e. V. Düsseldorf, Projekt 35 und Europäische Gemeinschaft fuer Kohle und Stahl (Nr. 7210 SA 1/108) 1983.

/3/ Наß, R.; Quast, U.: Brandverhalten von verbundstützen mit Berücksichtigung der unterschiedlichen Stützen/Riegel Verbindungen. Studiengesel lschaft für Anwendungstechnik von Eisen und Stahl e, V., Düsseldorf, Forschungsbericht P 86, Akt. 2.2 1985.

/4/ Haß, R.: Brandversuche an Stahlbeton- und Verbundstützen. Sonderforschungsbereich 148 Brandverhalten von Bauteilen, Technische Universität Braunschweig, Arbeitsbericht 1984 - 1986.

15/ Herschelmann, F.; Richter, E.: Parameterstudie für verbundträgexdecken der Feuerwiderstandsklasse "F 90". Studiengesellschaft für Anwendungstechnik von Eisen und Stahl e. V., Düsseldorf, Forschungsbericht P 86 Akt. 2.51984.

/6/ Dorn, T.; Haß, R.; Quast, U.: Brandverhalten und Bemessung von Anschlüssen zur Verländerung der Feuerwiderstandsdauer von Verbundkonstruktionen. Studiengesellschaft für Anwendungstechnik von Eisen und Stahl e. V., Düsseldorf, Forschungsbericht P 86 Akt. 2.10 1986.

/7/ Klingsch, K.-G.; Wuerker und R. Martin-Bullmann: Brandverhalten von Hohlprofi-Verbundstutzen, Verlag wilhelm Ernst \& Sohn, Berlin 1984, STAHLBAU 10/1984.

/8/ Klingsch, W.; Bode, H.-G.; Finsterle, A.: Brandverhalten von Verbundstützen aus vollständig einbetonierten Walzprofilen, Bauingenjeur 59 (1984), Heft 11.

19/ HaB, R. : Zur praxisgerechten brandschutztechnischen Beurteilung von Stützen aus Stahl und Beton. Institut für Baustoffe, Massivbau und Brandschutz, Technische Universität Braunschweig, 1986.

/10/ Kordina, K.; Meyer-Ottens, C.: Beton-Brandschutz-Handbuch. Betonverlag GmbH, Dueseldorf, 1981. 
